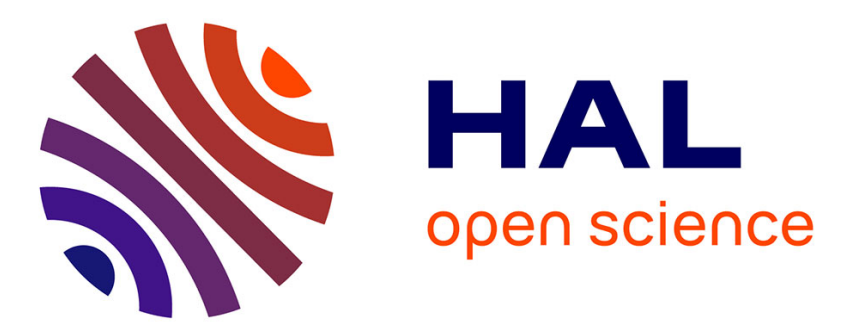

\title{
Removal of trimethylamine and isovaleric acid from gas streams in a continuous flow surface discharge plasma reactor
}

Aymen Amine Assadi, Abdelkrim Bouzaza, Marguerite Lemasle, Dominique

Wolbert

\section{To cite this version:}

Aymen Amine Assadi, Abdelkrim Bouzaza, Marguerite Lemasle, Dominique Wolbert. Removal of trimethylamine and isovaleric acid from gas streams in a continuous flow surface discharge plasma reactor. Chemical Engineering Research and Design, 2015, 93, pp.640-651. 10.1016/j.cherd.2014.04.026 . hal-01010208

\section{HAL Id: hal-01010208 \\ https://hal.science/hal-01010208}

Submitted on 23 Sep 2014

HAL is a multi-disciplinary open access archive for the deposit and dissemination of scientific research documents, whether they are published or not. The documents may come from teaching and research institutions in France or abroad, or from public or private research centers.
L'archive ouverte pluridisciplinaire HAL, est destinée au dépôt et à la diffusion de documents scientifiques de niveau recherche, publiés ou non, émanant des établissements d'enseignement et de recherche français ou étrangers, des laboratoires publics ou privés. 


\title{
Removal of trimethylamine and isovaleric acid from gas streams in a
} continuous flow surface discharge plasma reactor

\author{
Aymen Amine ASSADI ${ }^{\mathrm{a} b \mathrm{~b}}$, Abdelkrim BOUZAZA ${ }^{\mathrm{a}, \mathrm{b}^{*}}$, Marguerite LEMASLE $^{\mathrm{a}, \mathrm{b}}$, Dominique WOLBERT ${ }^{\mathrm{a}, \mathrm{b}}$ \\ ${ }^{\text {a }}$ Laboratoire Sciences Chimiques de Rennes - équipe Chimie et Ingénierie des Procédés, UMR 6226 \\ CNRS, ENSCR, 11 allée de Beaulieu, 35700 Rennes, France. \\ ${ }^{\mathrm{b}}$ Université Européenne de Bretagne. \\ * Corresponding author. Tel.: +33 2 23238056; fax: +33 223238120 . \\ E-mail address: Abdelkrim.bouzaza@ensc-rennes.fr (A. Bouzaza)
}

\begin{abstract}
The removal of isovaleric acid (IVA) and trimethylamine (TMA) using nonthermal plasma (NTP) in a continuous surface discharge reactoris investigated. The influence of the energy density shows that its increment is accompanied by the increase of the removal rate. Atflowrateequal to $2 \mathrm{~m}^{3} \cdot \mathrm{h}^{-1}$, whenenergy densityextends three times, the removal rates of IVA and TMAare increased from 5 to $15 \mathrm{mmol} \cdot \mathrm{m}^{-2} \cdot \mathrm{h}^{-1}$ and from 4 to $11 \mathrm{mmol} \cdot \mathrm{m}^{-2} \cdot \mathrm{h}^{-1}$,respectively. The impact of relative humidity (RH) is also studied. An increase in \% RH (up to 20\%) leads to a decrease of theremoval rate. Additionally, the formation of by-productsin thesurface discharge reactorand the plausible reaction mechanism of the two VOC were alsodetected and discussed.Moreover, a kinetic model taking into account the mass transfer step is developed in order to represent the experimental results. The model shows a good agreement with experimental results.
\end{abstract}

\section{Keywords}

Surface discharge, VOCs, mass transfer, relative humidity

\section{Introduction}

VOCs are hazardous to health and environment; their emission causes serious environmental problems such as stratospheric ozone depletion, photochemical smog, greenhouse effect and so on (US EPA, 2008;Le Cloirec, 1998). Increasing awareness of these emissions has resulted in legislation requiring stringent enforcement of new regulations to improve the quality of the environment (US EPA, 2008). To remove those gaseous 
pollutants, many technologies have been developed but they are not very successful and do not satisfy the strict social demands of the present ( Harling et al., 2008). One of the methods which are developed for the control of VOCs is nonthermal plasma processing. This latest process is a major area of research in both industry and academia (Le Cloirec, 1998; Harling et al., 2008; Mista et al., 2008).

It is characterized by the formation of electrons, ions and neutral molecules. Energetic electrons ionize and dissociate background molecules resulting in the formation of highly reactive chemical species (radicals, ions, excited molecules and ozone) (Khani et al., 2011). Literature has also shown that various types of electrical discharge have been investigated for the oxidation of hydrocarbons: pulsed corona discharge(Ouni et al., 2009), atmospheric pressure glow discharge(Yan et al., 2013), dielectric barrier discharge (DBD)(Mfopara et al., 2009; Ye et al., 2013], packed-bed discharge(Jiang et al., 2013, Goujard et al., 2011; Schmid et al., 2010) and surface discharge(Maciuca et al., 2012, Allegraud, 2007; Jolibois et al., 2012).

Recently, many research attempts have been made to make up for the advantages of DBD plasma reactors for particularly effective control of hazardous gas emissions and treating gas streams with low VOC concentrations at low temperature[Ouni et al., 2009; Jolibois et al., 2012). In fact, DBD plasmareactorshavebeen widely studied in the area of hazardous and toxic gases control, VOC abatement such as toluene (Mok et al., 2011; Huang et al., 20011; Subrahmanyama et al., 2010) and dimetylamine(Ye et al., 2013), $\mathrm{H}_{2} \mathrm{~S}$ and $\mathrm{NH}_{3}$ removal (Ma et al., 2001), $\mathrm{NO}_{\mathrm{x}}$ removal from the flue gas (Jolibois et al., 2012; Yoshida, 2013).

The aim of our study is to improve understanding of the physical and chemical mechanisms involved during nonthermal plasma (NTP) removal process of a typical VOC. In this work, isovaleric acid and trimethylamine are chosen as representative of odorous compounds. These compounds are the main molecules detected in the exhaust gases from animal quartering centers (ADEME, 2005).

The focus is put on the study of kinetic removal of these pollutants and the effect of relative humidity and some operating parameters.Moreover, in most cases, steady-state kinetic models with plasma process in the literatureignore the effect of mass transfer (Mokt et al, 2001). That could be presumed if turbulences in the system are high enough to consider the surfacereaction as the limiting step in the apparent removal rate(Redolfi et al., 2009). Thus, the influence of the mass transfer on the performance of NTP process will also be discussed. 


\section{Experimental}

\subsection{DBD plasma reactor}

The used DBD plasmareactor is composed principally of a glass tube $(58 \mathrm{~mm}$ id and $100 \mathrm{~cm}$ length) (Fig. 1). To generate the DBDplasma, the reactor is covered by a copper grid forming the outer electrode. The glass tube, $4 \mathrm{~mm}$ thickness, acts as the dielectric media. The inner electrode is on aluminum. The applied high voltage is about $30 \mathrm{kV} / 40 \mathrm{~mA}$ and is a sine waveform. The DBD plasma is obtained by submitting the electrodes to a sinusoidal high voltage ranging from 0 to $30 \mathrm{kV}$ at a $50 \mathrm{~Hz}$ frequency(Fig.1). The outer electrode is connected to the ground through a 2.5 nFin order to collect the charges transferred through the reactor(Manley, 1943). Theapplied voltage $\left(U_{a}\right)$ and high capacitance voltage $\left(U_{m}\right)$ are measured by LeCroy high voltage probes and recorded by a digital oscilloscope (Lecroy Wave Surfer 24 Xs, 200 MHz) (Fig.1).

The design of this reactor (Fig.1) is the subject of a Patent Application BFF11L1041/MFH (CIAT Patent, 2013).

The pollutants, isovaleric acid (IVA)andtrimethylamine (TMA), are injected continuously using a syringe/syringe driver system (Kd Scientific Model 100) through a septum into the gas stream. A heating system covering the injection zone sets the gas temperature and facilitates the VOC vaporization ahead of the static mixer (Fig.2.a). The treated flowratestream varies from 2 to $10 \mathrm{~m}^{3} \cdot \mathrm{h}^{-1}$.

Fig.1

Fig.2.b

\subsection{Product analysis}

IVA analysisisperformed by FID-Gas chromatography (Fisons Chromatograph). A Chrompact FFAP-CB column ( $25 \mathrm{~m}$ of length $0.32 \mathrm{~mm}$ of external diameter $0.32 \mathrm{~mm}$ ), which is specially adapted for volatile fatty acids is used. Nitrogen gas constitutes the mobile phase. All injections are performed manually with a syringe of $250 \mu 1$. 
The TMAis analyzed by a gas chromatograph equipped with a nitrogen-phosphor detector (NPD). The column is a capillary column VOLAMINE, its length is $60 \mathrm{~m}$. The sample injection is done with a syringe of $500 \mu 1$.

The experiments which are repeated two times; show a good reproducibility with 5\% standard deviation. This standard deviation is represents by vertical bars in the experimental results in all figures.

An effort is also made to quantify the major reaction intermediates present in gas phase in order to determine the main reaction routes and to better understand the mechanisms involved.

The byproducts generated during the DBD plasma oxidation of IVA and TMAare identified and evaluated by Gas Chromatograph-Mass spectrometer (GC-MS) (Perkin Elmer Clarus 500) equipped with an infrared (IR) detector.The temperature conditions in the oven, the injection chamber and the detector are, respectively, 100, 120 and $200{ }^{\circ} \mathrm{C}$.

Due to their low concentrations, byproducts are concentrated in a Carbotrap $(25 \mathrm{ml})$ then removed by thermal desorption unit coupled with GC-MS.

At the exit of the DBD plasmareactor a constant flowrate of $200 \mathrm{~L} / \mathrm{h}$ is bubbled on iodine solution. Standard iodometric titration method is used to estimate the downstream ozone formation (Rakness et al., 1996). $\mathrm{NO}_{\mathrm{x}}$ and $\mathrm{CO}$ concentrations are measured by an NO/CO ZRE gas analyzer. The $\mathrm{CO}_{2}$ concentrationis analyzedby a FourierTransform Infrared (FTIR) spectrophotometer brand Environnement SA (Cosma Beryl reference 100). The measurement accuracy is about $5 \%$.

The removal rate $(\mathrm{R})$ of IVA and TMA at any value of specific energy is calculated as:

$$
R=\left(\frac{Q}{S_{\text {plasma }}}\right) \cdot\left(C_{\text {in }}-C_{\text {out }}\right)
$$

Where $\mathrm{C}_{\text {in }}$ and $\mathrm{C}_{\text {out }}$ are the inlet and the outlet pollutant concentrations $\left(\mathrm{mmol} . \mathrm{m}^{-3}\right)$, respectively; $\mathrm{Q}$ is the volumetric flowrate $\left(\mathrm{m}^{3} \cdot \mathrm{h}^{-1}\right)$ and $S_{\text {plasma }}$ the active surface of plasma $\left(\mathrm{m}^{2}\right)$.

Moreover we use the Lissajous plot method (Manley, 1943) for estimating mathematically the power input (P) (fig. 2.b). $\mathrm{P}$ is obtained by multiplying the pulse frequency $(\mathrm{Hz})$ and the specific energy (SE) over a period (eq.3).

$$
\mathrm{P}(\mathrm{W})=\mathrm{SE}(\mathrm{J}) \text { xfrequency }(\mathrm{Hz})
$$

The energy density (ED) is then calculated as:

$$
\mathrm{ED}(\mathrm{J} / \mathrm{L})=\left(3600 \mathrm{x} \mathrm{P}(\mathrm{W}) / \mathrm{Q}\left(\mathrm{m}^{3} \cdot \mathrm{h}^{-1}\right)\right) / 1000
$$


The energy density (ED) value isvaried by changing the applied voltage $\left(U_{a}\right)$.

\section{Fig.2.b}

The removal of isovaleric acid and trimethylamine in the DBD plasma reactor is evaluated at several gas residence times, water vapor concentrations and influent pollutant concentrations (Table 1).

\section{Table 1}

N.B.: The corresponding residence times in the annular plug-flow reactor for gas flowrates equal to 2, 4 and $6 \mathrm{~m}^{3} \cdot \mathrm{h}^{-1}$ are respectively $1.2,0.8$ and $0.5 \mathrm{~s}$.

The $\mathrm{CO}_{2}$ overall selectivity ( $\mathrm{CO}$ overall selectivity can also be defined) may be a useful parameter to assess the performance of the DBD plasma reactor towards VOC removal. It allows an estimation the mineralization rate i.e. the ultimate reaction step, of the process.

The $\mathrm{CO}_{\mathrm{x}}$ Overall selectivity is expressed as follow (eq. 4\&5):

$$
\left\{C O_{x} \text { 's overall selectivity }(\%)\right\}_{I V A}=\frac{\left[C O_{x}\right]_{I V A}^{\text {out }}-\left[C O_{x}\right]_{I V A}^{\text {in }}}{5 \times[I V A]^{\text {in }} \times\{\% \text { conversion }\}_{I V A}} \times 10^{4}(4)
$$

$$
\left\{C O_{x} \text { 's overall selectivity }(\%)\right\}_{T M A}=\frac{\left[C O_{x}\right]_{T M A}^{\text {out }}-\left[C O_{x}\right]_{T M A}^{\text {in }}}{3 \times[T M A]^{\text {in }} \times\{\% \text { conversion }\}_{T M A}} \times 10^{4}(5)
$$

where $\mathrm{x}=1$ for $\mathrm{CO}$ and $\mathrm{x}=2$ for $\mathrm{CO}_{2}$. $\left[\mathrm{CO}_{\mathrm{x}}\right]_{\mathrm{IVA}},\left[\mathrm{CO}_{\mathrm{x}}\right]_{\mathrm{TMA}}$ are respectively obtained after the removal of IVA and TMA. $[\text { IVA }]^{\text {in }}$ and $[\text { TMA }]^{\text {in }}$ are respectively the inlet concentration of IVA and TMA.

The coefficients 5 and 3 are the stoechiometric coefficients of the removal reaction.

The carbon balance (CB) is defined as the ratio (expressed in percentage) of the number of moles of carbon present in the reaction products relative to their respective moles in each pollutant removed.

$\mathrm{CB}$ values of IVA and TMA are expressed as:

$$
\begin{gathered}
{[\mathrm{CB}(\%)]_{I V A}=\frac{[\text { CO }]+\sum[\text { other byproducts }]}{5 \times[\text { IVA }]^{\text {in }} \times\{\% \text { IRE }\}_{\text {IVA }}} \times 100 \%} \\
{[\mathrm{CB}(\%)]_{T M A}=\frac{[\text { CO } x]+\sum[\text { other byproducts }]}{3 \times[T M A]^{\text {in }} \times\{\% \text { IRE }\}_{\text {TMA }}} \times 100 \%}
\end{gathered}
$$




\section{Results and Discussion}

\subsection{Flowrate and energy density}

\subsubsection{The removal rate}

The removal rate of each VOC is studied by varying the energy density and flowrate (Fig.3a and 3.b).

\section{Fig. 3.a}

\section{Fig. 3.b}

In the first instance, the effect of ED shows thatwhen this parameter increases the removal rates of IVA and TMA increase also(Fig.3.a \& b). In fact, at flowrate equal to $2 \mathrm{~m}^{3} / \mathrm{h}$, when EDextends three times, the removal rates of IVA and TMA are increased from 5 to 15 mmol. $\mathrm{m}^{-2} \cdot \mathrm{h}^{-1}$ and from 4 to $11 \mathrm{mmol} \cdot \mathrm{m}^{-2} \cdot \mathrm{h}^{-1}$, respectively. This result is similar to those reported for trichloromethane (Schmidt-Szałowski et al., 2011) acetylene (Redolfi et al., 2009) and toluene (Vandenbroucke et al., 2011),

This behavior was expected, as increasing the electric voltage across the reactor leads to higher degree of ionization and higher reactive species production (Thevenetet al., 2008; Wang et al., 2009). Therefore the pollutant has more probability to be attacked by electrons or radicals, resulting in enhancing removal rates of IVA and TMA. Similar results have been reported in the literaturefor some VOCs (Fridman, 2008; Vandenbrouckeet al., 2011).

By comparing the removal rate of each VOC, Fig. 3.a \& b show that IVA is easier to be removed. In fact, at an ED of $17 \mathrm{~J} /$ Land flowrate of $6 \mathrm{~m}^{3} \cdot \mathrm{h}^{-1}$, the removal rate of IVA can reach $39 \mathrm{mmol} \cdot \mathrm{m}^{-2} \cdot \mathrm{h}^{-1}$ where the removal rate of TMA is equal to $27 \mathrm{mmol} \cdot \mathrm{m}^{-2} \cdot \mathrm{h}^{-1}$.

The chemical bond strength and molecule stability are the main factors that can affect the removal rate of VOCs in the NTP process(Schmidt-Szałowski et al., 2011; Wang et al., 2009;Assadi, 2012).

We note that, at a low value of ED, the effect of the flowrate is not important. This effect can be explained that, at these conditions, low electrons and reactive species (such as ${ }^{\circ} \mathrm{O}$ and ${ }^{\circ} \mathrm{OH}$ ) are formed. Thus, the removal rate is probably limited by the chemical step.

A similar trend is observed for the two studied VOCs. 
Thus, at high values of ED, the flowrate has more influence on the removal rate. The mass transfer becomes the limited step. This is due to that, in laminar regime, the flowrate increaseinvolves higher values of the Reynolds number $\left(R_{e}\right)$ from 368 to 1103 and mass transfer coefficient $\left(k_{\mathrm{m}}\right)$ (Assadi et al.,2012).

\subsubsection{The overall selectivities of $\mathrm{CO}$ and $\mathrm{CO}_{2}$}

The increase of ED leads to an increase of the overall selectivities (Fig 4.a\&b). This is due to the fact that more electrons and reactive species (such as ${ }^{\circ} \mathrm{O}$ and ${ }^{\circ} \mathrm{OH}$ ) are formed when the $\mathrm{ED}$ increases and then more pollutants molecules are oxidized into $\mathrm{CO}_{2}$ and $\mathrm{CO}($ Guaitella et al., 2008). In fact, with TMA, an increase inED from 9 to $17 \mathrm{~J} / \mathrm{L}$ leads to $\mathrm{CO}$ and $\mathrm{CO}_{2}$ overall selectivity increase from 4 to $11 \%$ and from 16 to $25 \%$, respectively. These results are in agreement with works on removal of toluene with plasma(Guo et al., 2006; Huang et al., 2011; Liang et al., 2009), isovaleraldehyde (Maciuca et al., 2012), acetylene (Thevenet et al., 2008 ; Guaitella et al.,2008), acetone (Schmid et al., 2010), benzene (Jiang et al., 2013; Fan et al., 2009) and dimethylamine (Ye et al., 2013).

Fig. 4.a

Fig. 4.b

In other hand, the mineralization of TMA is better than that of IVA. This can be explained by the fact that less TMA is converted to intermediate compared to isovaleric acid. Thus the intermediates have more probability to be attacked by electrons and active species.

\subsection{Relative humidity}

Many works (Thevenet et al.,2008; Vandenbrouckeet al., 2011) reported that relative humidity $(\mathrm{RH})$ can considerably alter the performances of NTP.

Water plays a very important role in the reaction since it decomposes into ${ }^{\circ} \mathrm{OH}$ and ${ }^{\circ} \mathrm{H}$ free radicals in the plasma system (Ogata et al., 2004; Atkinson et al., 2003):

$$
\mathrm{H}_{2} \mathrm{O}+\mathrm{e}^{-} \rightarrow{ }^{\cdot} \mathrm{H}+{ }^{\circ} \mathrm{OH}+\mathrm{e}^{-}(1)
$$

When $\mathrm{RH}$ is high, more $\mathrm{H}_{2} \mathrm{O}$ molecules collide with high energy electrons and $\bullet \mathrm{OH}$ radicals are formed. 
227 Generally, VOCs can be removed by NTP via two pathways including (a) direct electron attack and (b) indirect gas phase radical reactions (reactions between VOC molecules and atomic oxygen ${ }^{\circ} \mathrm{O}$ or gas phase radicals such as $\left.{ }^{\circ} \mathrm{OH}\right)($ Ogata et al., 2002). On one side, water molecules partially dissociate to form reactive species (Khani et al., 2011; Ouni et al., 2009; Vandenbrouckeet al., 2011). On the other side, water negatively influences VOC removal due to its electronegative characteristics. Due to high water concentrations, increased plasma attachment processes result in a reduced hydroxyl radical $\left({ }^{\circ} \mathrm{OH}\right)$ production. It can be concluded that two opposite phenomena are involved: water partially dissociates in the plasma leading to reactive species, but humidity also negatively influences the plasma characteristics. (Mista and Kacprzyk, 2008; Goujard et al., 2008; Capitelli, 1965).

So it will be interesting to study the influence of RH on the IVA and TMA removal.

\subsubsection{The removal rate}

The variation of removal rate of IVA and TMA with respect to RH is represented on Fig.5.a and 5.b. Tests are performed at $20 \%, 55-60 \%$ and $85-90 \%$ RH.

Fig. 5.a.

Fig. 5.b.

We note that increasing water in the stream leads to a decrease of TMA's removal rate (Fig.5.b).

It is unlikely that ${ }^{\circ} \mathrm{OH}$ radicals produced from water dissociation are responsible for TMA removal. As a result of decreased electron density with increasing $\mathrm{RH}$, the removal rate of TMA decreases.

As reported by Guaitella et al (Guaitella et al, 2008) and Thevenet et al (Thevenet et al, 2008), oxygen atomic plays an important role on VOC oxidation under dry plasma treatment. The disappearance of this specie due to $\mathrm{H}_{2} \mathrm{O}$ electron scavenging could explain the decrease of the removal rate of VOC with an increasing $\mathrm{H}_{2} \mathrm{O}$ amount.

On the contrary, the removal rate of IVA by NTP is slightly promoted by increasing ofRH from $20 \%$ to $50-60 \%$ (Fig. 5.a). This is probably due to the enhanced production of ${ }^{\circ} \mathrm{OH}$ radicals, since the $\mathrm{C}-\mathrm{O}$ substituent in isovaleric acid molecule can be more easily oxidized by radicals as compared to the $\mathrm{N}-\mathrm{C}$ link. 
Adding more water in inlet gas mixture ( $\mathrm{RH}>60 \%)$ has a negative effect on the removal rate of IVA due to its electronegative characteristics. At higher RH electron density is reduced and some reactive species are then quenched(Ogata et al., 2004; Thevenet et al., 2008).

\subsubsection{The overall selectivity of $\mathrm{CO}_{2}$}

The water vapour seems to play an important role on byproducts formation. $\mathrm{CO}_{2}$ overall selectivity increases when RH increases. This tendency is the same for the two pollutants studied (Fig 6 a. \& b).

Fig.6.a

Fig 6.b

When $\mathrm{RH}$ raises from 25 to $90 \%$, at $\mathrm{ED}$ equal to $16.5 \mathrm{~J} / \mathrm{L}, \mathrm{CO}_{2}$ 's overall selectivity of IVA and TMA increases from 25 to $34 \%$ and from $21 \%$ to $30 \%$, respectively.

As described previously, the water vapor is essential to the formation of ${ }^{\circ} \mathrm{OH}$ and ${ }^{\circ} \mathrm{O}$ which promotes the mineralization of byproducts (Thevenet et al., 2008; Futamura et al., 1997).Moreover, several authors (Thevenet et al., 2008; Ogata et al., 2004) report that CO and $\mathrm{CO}_{2}$ would be related by equilibrium under plasma action. In fact, water would be supposed to favor the oxidation of $\mathrm{CO}$ leading to $\mathrm{CO}_{2}$. In fact, the presence of ${ }^{\circ} \mathrm{OH}$ radicals shifts the equilibrium towards the formation of $\mathrm{CO}_{2}$.

\subsubsection{On the ozone formation}

Ozone is an inevitable byproduct in a NTP. Atomic oxygen ${ }^{\circ} \mathrm{O}$ is generated by molecular dissociation due to an impact with high energy electrons (reaction 2).

$$
\mathrm{e}^{-}+\mathrm{O}_{2} \rightarrow \mathrm{e}^{-}+{ }^{\circ} \mathrm{O}+{ }^{\circ} \mathrm{O}
$$

Atomic oxygen is a strong oxidizer, but its stability is very limited. Due to fast recombination processes, the lifetime is only few microseconds at atmospheric pressure (Aggadi, 2006;Atkinson et al., 2003).

Atomic oxygen reacts with molecular oxygen in three-body collisions, forming ozone by the following reaction:

$$
{ }^{\circ} \mathrm{O}+\mathrm{O}_{2}+\mathrm{M} \rightarrow \mathrm{O}_{3}+\mathrm{M}
$$


where M can be either molecular oxygen or molecular nitrogen (Atkinson et al., 2003).

The effect of ED on ozone formation is presented in Fig. 7.a and b. Whatever the value of RH and the used VOC, the ozone formation follows the same trend i.e. it increases with the ED. This can be explained by the fact that more electrons and reactive species (such as ${ }^{\circ} \mathrm{O}$ ) are formed and then atomic oxygen reacts with molecular oxygen in three-body collisions, (reactions $2 \& 3$ ) leading to ozone production(Redolfi et al., 2009).

Moreover, the decrease in ozone formation is also observed when RH increases. The quantity of the produced ozone is reduced two times when the RH increases from 25 to $90 \%$.

In fact, the formation of ozone is inhibited due to a series of radical reactions leading to fast ozone consumption (Atkinson et al., 2003). The presence of water molecules activates the reaction giving ${ }^{\bullet} \mathrm{OH}$ and ${ }^{\bullet} \mathrm{O}_{2} \mathrm{H}$ radicals which react with ozone.

- $\quad$ First, water acts as electron acceptor, following this pathway (Atkinson et al., 2003):

$$
\mathrm{H}_{2} \mathrm{O}+\mathrm{e}^{-} \rightarrow{ }^{\bullet} \mathrm{H}+{ }^{\bullet} \mathrm{OH}(4)
$$

- Then ozone is decomposed by ${ }^{\bullet} \mathrm{H}$ and ${ }^{\bullet} \mathrm{HO}$ radicals(Atkinson et al., 2003; Braci et al., 2011):

$$
\begin{aligned}
\mathrm{O}_{3}+{ }^{\bullet} \mathrm{OH} \rightarrow & \mathrm{O}_{2}+{ }^{\bullet} \mathrm{O}_{2} \mathrm{H}(5) \\
& \mathrm{O}_{3}+{ }^{\bullet} \mathrm{H} \rightarrow \mathrm{O}_{2}+{ }^{\bullet} \mathrm{OH}(6)
\end{aligned}
$$

Globally, the effect of $\mathrm{RH}$ on the ozone production is relatively important.

\section{Fig.7.a}

\section{Fig.7.b}

\subsection{Gas phase reaction intermediates}

Byproducts formation is an important factor to be taken into account when NTP process is carried out. VOCs removal often leads to the formation of some byproducts (Thevenet et al., 2008; Vandenbrouckeet al., 2011).

Fig.4.a and 4.b show that CBof each pollutant is achieved. This means that the majority of organic byproducts are released from theDBD plasma reactor.

The gas stream in the exit of DBD plasma reactor is analyzed in order to identify the formed byproducts. This is done in order to understand the reaction mechanism.

\subsubsection{Case ofIVA}


326 An air stream of $2 \mathrm{~m}^{3} \cdot \mathrm{h}^{-1}$ containing $55 \mathrm{ppm}$ of IVAis treated in DBD plasma reactor. Six

327 byproducts are identified (Fig.8.a): acetone $\left(\mathrm{CH}_{3} \mathrm{COCH}_{3}\right)$, isobutyric acid $\left(\mathrm{CH}_{3} \mathrm{CH}_{2} \mathrm{CH}_{2}\right.$ -

$328 \mathrm{COOH})$, methanol $\left(\mathrm{CH}_{3} \mathrm{OH}\right)$, acetic acid $\left(\mathrm{CH}_{3} \mathrm{COOH}\right), \mathrm{CO}$ and $\mathrm{CO}_{2}$.

329

330

331

332

333

334

335

336

337

338

339

340

341

342

343

344

345

346

347

348

349

350

351

352

353

354

355

356

357

358
Fig.8.a

A removal pathway is proposed from literature study and is checked through experimental investigations (Assadi, 2012; Aggadi,2006). The oxidation scheme of IVA consists of the simultaneous carboxylic function removal and new function carried on an ' $n-1$ ' carbon molecule. So a possible removal pathway in series, whichleads to a complete mineralization, is proposed inFig. 8.b.

Fig.8.b

Standard plasma radical kinetics based on ${ }^{\circ} \mathrm{O}$ and ${ }^{\circ} \mathrm{OH}$ oxidation of the compounds fails to explain this distribution of the byproducts. Therefore the decomposition of $\mathrm{C}_{5} \mathrm{H}_{10} \mathrm{O}_{2}$ in the discharge must proceed through a fast cleavage of the $\mathrm{C}-\mathrm{C}$ and $\mathrm{C}-\mathrm{O}$ bonds. Several processes can be implied in the removal mechanism: direct electronic impact and chemical reactions with ions or nitrogen excited states (Huang et al., 2011; Atkinson et al., 2003).

\subsubsection{Case of TMA}

Byproducts due to TMAremovalare also analyzed. Thus (Dimethylamino) acetonitrile, N, NDimethyl formamide, Nitromethane, acetone, acetic acid, methanol and ethanol are identified (Fig.8.a).

The removal mechanism of trimethylamine seems to be more complex than isovaleric acid. Byproducts containing nitrogenwould be formed at different removal steps.

Fig. 9.a

Moreover the oxidation of the trimethylamine leads to the formation of $\mathrm{NO}_{\mathrm{x}}$. The amounts of these byproducts are represented in Fig.9.b

Fig.9.b 
Therefore, in our opinion, the possible removal pathway is that (Dimethylamino) acetonitrile, N, N-Dimethyl formamide, Nitromethaneat atmospheric pressure are essentially produced by the reactionof methyl radical with $\mathrm{NO}_{2}$ (Braci et al., 2011, Harling et al., 2009, Aggadi, 2006).

Moreover it is possible that after the main oxidation reactions another "combinationreactions" can occurs between byproducts(Schmidt-Szalowski et al., 2011; Yoshida, 2013). Maybe acetone and acetic acid are essentially due to TMA "fragments" oxidation by CO. While methanol and ethanol formation is due to acetic acid oxidation.

\subsection{Modelling of kinetics and influence of the mass transfer}

\subsubsection{Model without mass transfer (WMT)}

During the oxidation process in DBD plasma reactor two main steps can be considered: the mass transfer step and the chemical reaction step. Usually the mass transfer stepis neglected. Many authors (Goujard et al., 2011; Mokt et al., 2001; Wang et al., 2009; Redolfi et al., 2009)work only in batch reactor where mass transfer does not impact the kinetics, due to a perfectly mixed gas phase.

By applying a mass balance over the entire length of the reactor we obtain:

$$
D_{e} \frac{d\left(C_{b}\right)^{2}}{d^{2} z}-u_{0} \frac{d C_{b}}{d z}=R(8)
$$

where $D_{e}$ is the axial dispersion coefficient, $C_{b}$ is the concentration of VOC on the gas phase, $\mathrm{u}_{0}$ is the linear velocity in the reactor, $\mathrm{z}$ is any position along the reactor longitudinal axis and $\mathrm{R}$ is the removal rate. Moroever, here, the reactor has been confirmed as a plug-flow reactor (Assadi et al., 2012). In fact, a residence time distribution (RTD) experiment was carried out using carbon dioxide as a tracer substance. This lastwas injected during a very short time interval into the reactor (Dirac function). The outlet carbon dioxide concentration is measured at the exit of reactor. The tanks in series model were used to describe the response of the system. The experiments of RTD revealed that our annular reactor could be assimilated to a cascade of 22 elementary continuously stirred tank reactors. It is generally accepted that above a number of 20 elementary reactors, the experimental reactor can be considered as a plug flow reactor(Vincent et al., 2008). Thus, the continuous pollutant removal along the radial 
direction should not be ignored (Assadi, 2012; Guaitella et al., 2008). On the other side, the axial dispersion can be neglected and the equation (9) can be expressed as:

$$
-u_{0} \frac{d C_{d}}{d z}=R(9)
$$

Moreover, many authors use the relation (10) to identify the removal rate of toluene and acetone (Schmid et al.,2010;Chang et al., 2005), nitric oxide (Mokt et al., 2001), cyclohexane(Harling et al., 2009)and isovaleraldehyde (Maciuca et al., 2012)on the DBD plasma reactors. This removal rate can be written as:

$$
R=k_{d} C_{d} \frac{P}{V_{\text {reactor }}}=k_{d} C_{d} \frac{E_{\text {inj }}}{V_{\text {reactor }}} \cdot Q=k_{d} C_{d} \frac{E_{\text {inj }}}{\tau}(10)
$$

where $\mathrm{k}_{\mathrm{d}}$ is the apparent rate constant, $\mathrm{C}_{\mathrm{b}}$ and $\mathrm{C}_{\mathrm{d}}$ are concentrations of VOC on the bulk and discharge phases respectively, $\mathrm{V}_{\text {reactor }}$ is the reactor volume and $\mathrm{P}$ is the discharge power, $\tau$ is the residence time of the pollutant on the DBD plasma reactor and Q is the flowrate.

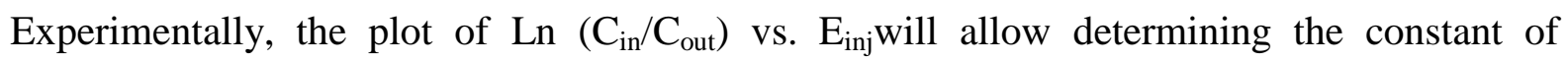
modelWMT.The values of the apparent rate constants $\left(\mathrm{k}_{\mathrm{d}}\right)$ are represented on table 2 . We note that the model WMT represents the experimental results with a good approach. However the apparent constants of this model are flowrate dependent. Thus, we can conclude that the mass transfer step cannot be neglected in this present study. Therefore the model that will be developed below will reflect the influence of the transfer step.

\section{Table 2}

\subsubsection{Model with mass transfer (MT)}

In air,under atmospheric pressure, the electrical discharge is considered as filamentary. Each time the discharge takes place, electrons and active species such as ions, radicals and excited species are generated at the surface of glass tube. They recombine rapidly into more stable species and can further diffuse in the bulk phase (Allegraud et al, 2007; Capitelli et al., 2000). The short life duration of radicals such as atomic oxygen ${ }^{\circ} \mathrm{O}$ makes that, in the bulk phase, only the ozone is present(Allegraud et al., 2007; Vandenbrouckeet al., 2011).

Thus, the plasma process is broken down into two phases:

- Transfer of gaseous reagents from gas phase to the discharge phase

- Oxidation reaction between gaseous reagents on the discharge phase.

By applying a mass balance over the two phases of the reactor we obtain: 
425 Discharge phase: $T=k_{d} C_{d} \frac{P}{V}(12)$

426 Where $\mathrm{T}$ is the mass transfer between the two phases. It can be estimated as(Bouzaza et al., 427 2006):

$$
T=k_{m} a_{v}\left(C_{b}-C_{d}\right)(13)
$$

429 where $\mathrm{k}_{\mathrm{m}}$ is the mass transfer coefficient $\left(\mathrm{m} \cdot \mathrm{s}^{-1}\right)$ and $a_{\mathrm{v}}$ is the area of discharge per unit 430 volume of the reactor $\left(\mathrm{m}^{2} \cdot \mathrm{m}^{-3}\right) \cdot \mathrm{a}_{\mathrm{v}}$ is kept constant and is equal to $134 \mathrm{~m}^{2} \cdot \mathrm{m}^{-3}$.

431 The external mass-transfer coefficient, $\mathrm{k}_{\mathrm{m}}$ is estimated using a correlation developed for 432 laminar flow in annular reactors(Mobarak et al.,1997):

$$
S h=1,029 \times S c^{0,33} \times \operatorname{Re}^{0.55} \times\left(\frac{L_{t o t}}{d}\right)^{-0,472}
$$

434

435

where $\mathrm{L}_{\text {tot }}$ is the length of the annular reactor, $\mathrm{d}$ is its equivalent diameter, and $\mathrm{Sh}, \mathrm{Sc}$ and $\mathrm{Re}$ are respectively Sherwood, Schmidt and Reynolds dimensionless numbers. The values of $\mathrm{Re}$ and $\mathrm{k}_{\mathrm{m}}$ are given in table 3 .

\section{Table 3}

By combining equations (11) and (12), an algebraic resolution from $\mathrm{z}=0$ to $\mathrm{z}=\mathrm{L}$ and $\mathrm{C}$ from $\mathrm{C}_{\text {in }}$ to $\mathrm{C}_{\text {out }}$, gives:

$$
C_{b}(z=L)=C_{0} \cdot \exp \left[-\left(\frac{k_{m} a_{v}}{u_{0}}\right) \cdot\left(1-\left(\frac{1}{1+\frac{k_{d} \cdot E_{i n j}}{\tau \cdot k_{m} a_{v}}}\right)\right) \cdot L\right]_{(15)}
$$

The constant $\mathrm{k}_{\mathrm{d}}$ of each pollutant is determined by numeric resolution using solver Excel. For each experimental point, a target cell is defined as the difference between the experimental and the theoretical removal rate.
The value of the apparent rate constant $\mathrm{k}_{\mathrm{d}}$ obtained is summarized in Table 4.

\section{Table 4}


450 Fig. 3.a and 3.b show that the model is adequate to correlate the experimental results.

451 According to the literature, these results are in agreement with those reported for some VOCs

452 (Subrahmanyama et al., 2010,Wang et al., 2009; Redolfi et al., 2009).

453 In addition, it is interesting to note that this constant is not flowrate dependent. The influence

454 of this last parameter is integrated on the expression of $\mathrm{k}_{\mathrm{m}}$. In fact, the separation between the

455 mass transfer and the chemical reaction steps is obtained.

456

457

\section{Conclusions}

458

459

We have unambiguously shown that the removal rate of IVA and TMA can be improved by increasing the energy density. The increase of flowrate leads to a better removal rate of tested VOCs.

462 On the other hand, at higher levels of $\mathrm{RH}$, an inverted trend occurs and the removal of the two

463 VOCs becomes slightly lower. Intermediates byproductsare also identified. Thus, removal pathways of the pollutants are also proposed.

465 Moreover, a model based on chemical and mass transfer steps is developed to represent the experimental results. The influence of mass transfer is estimated by using semi-empirical model. Thus an apparent rate $\left(\mathrm{k}_{\mathrm{d}}\right)$ and mass transfer $\left(\mathrm{k}_{\mathrm{m}}\right)$ constants are determined independently.

This model describes successfully the removal of IVA and TMA by DBD plasma.

\section{Acknowledgment}

472

The authors gratefully acknowledge the financial support provided by the French National Research Agency (ANR) for this research work. 


\section{References}

485

ADEME, 2005. Pollutions olfactives : origine, législation, analyse, traitement, Ademe, Dunod, Angers.

488

Allegraud K., 2008. Décharge à barrière diélectrique de surface : physique et procédé, thèse Ecole polytechnique de Paris.

491

492

493

Aggadi N.,2006. Étude de la réactivité de suies modèles de n-hexane sous décharge couronne 494

495 pulsée à la pression atmosphérique, Université de Paris Nord-France

496

Assadi A.A., 2012. Développement d'un procédé de couplage réacteur plasma DBD-réacteur 497 photocatalytique pour le traitement des effluents gazeux : du laboratoire à l'application industrielle, Thèse $\mathrm{n}^{\circ}$ 009. Rennes: ENSC Rennes.

498

Atkinson R., Baulch D. L., Cox R. A., Crowley J. N., Hampson R. F., Hynes R. G., Jenkin M. E., Rossi M. J., Troe J., 2003. Evaluated kinetic and photochemical data for atmospheric chemistry: Part 1 - gas phase reactions of Ox, HOx, NOx and SOx species Atmospheric chemistry and Physics Discussions, 3, 6179-6699.

503

Bouzaza, A., Vallet, C., Laplanche, A., 2006. Photocatalyticremoval of some VOCs in the gas 505 phase using an annular flow reactor determination of the contribution of mass transfer and chemical reaction steps in the photodegradation process. J. Photochem. Photobiol. A: Chem.

Braci L., Ognier S., Liu Y.N., Cavadias S., 2011. Post-discharge treatment of air effluents 511

512 Capitelli M., Ferreira C.-M., Gordiets B., Osipov A., 2000. Plasma kinetics in atmospheric gases, C.-M. Ferreira, B. Gordiets, A. Osipov (Eds.), in: Springer Series on Atomic, Optical, and Plasma Physics, Eds 31, Springer-Verlag, Berlin. 
Capitelli M., 1965. Plasma Kinetics in Atmospheric Gases, New York -Springer.

Chang Ch.-L., Lin T.-Sh., 2005. Decomposition of Toluene and Acetone in Packed Dielectric Barrier discharge Reactor, Plasma Chemistry and Plasma Processing, 25, 227-243.

Derakhshesh M., Abedi J., Hassanzadeh H., 2010, Mechanism of methanol decomposition by non-thermal plasma, Journal of Electrostatics 68, 424-428.

Fan H.Y., Shi C. , Li X.S. , Zhao D. Z., Xu Y., Zhu A.M., 2009. High-efficiency plasma catalytic removal of dilute benzene from air, Journal of Physics D-Applied Physics 42 225105- 225110.

Fridman A. 2008. Plasma chemistry. New York: Cambridge University Press.

Futamura S., Zhang A. H., Yamamoto T., 1997. the dependence of non thermal plasma behavior of VOCs on their chemical structures Jwournal of Electrostatics 42, 51-62.

Goujard V., Tatibouet J-M., Batiot-Dupeyra C., 2011. Carbon Dioxide Reforming of Methane Using a Dielectric Barrier Discharge Reactor: Effect of Helium Dilution and Kinetic Mode, Plasma Chem Plasma Process 31, 315-325.

Guaitella O., Thevenet F., Puzenat E., Guillard C., Rousseau A., 2008. $\mathrm{C}_{2} \mathrm{H}_{2}$ oxidation by plasma $/ \mathrm{TiO}_{2}$ combination: Influence of the porosity, and photocatalytic mechanisms under plasma exposure, Applied Catalysis B: Environmental, 80, 296-305.

Guo Y. F., Ye D.-Q., Chen K.-F, Tian Y.F., 2006. Humidity Effect on Toluene Decomposition in aWire-plate Dielectric Barrier Discharge Reactor, Plasma Chem Plasma Process 26, 237-249.

Harling A. M., Glover D. J., Whitehead J. C., Zhang, K., 2008. Industrial Scale Destruction of Environmental Pollutants using a Novel Plasma Reactor, Ind. Eng. Chem. Res. 47, 5856-586. 
Jolibois J., Takashima K., Mizuno A., 2012. Application of a non-thermal surface plasma

550 discharge in wet condition for gas exhaust treatment: NOx removal, Journal of Electrostatics, 70, 300-308.

552

Harling A.M., Glover D. J., Whitehead J. Ch., Zhang K., 2009. The role of ozone in the

554 plasma-catalytic destruction of environmental pollutants, Applied Catalysis B: Environmental $55590,157-161$.

556

557

Huang H., Ye D., Leung D. Y. C., 2011. Abatement of Toluene in the Plasma-Driven 558 Catalysis: Mechanism and Reaction Kinetics, IEEE transactions on plasma science, 39, 877559 882 .

560

Jiang N., Lu N., Shang K., Li J., Wu Y., 2013. Effects of electrode geometry on the performance of dielectric barrier/packed-bed discharge plasmas in benzene degradation. Journal of Hazardous Materials 262, 387-393

564

Jiwu L., Lei F., 2013. Modeling of corona discharge combined with $\mathrm{Mn}^{2+}$ catalysis for the 566 removal of $\mathrm{SO}_{2}$ from simulated flue gas, Chemosphere 91, 1374-1379

567

Khani M.R., RazaviBarzoki S.H., SahbaYaghmaee M., Hosseini S.I., Shariat M., Shokri B., Fakhari A.R., Nojavan S., Tabani H., Ghaedian M., 2011. Investigation of cracking by cylindrical dielectric barrier discharge reactor on the n-hexadecane as a model compound, IEEE Trans. Plasma Sci. 39, 1807-1813.

572

Le Cloirec P., 1998. Les composés organiques volatils dans l'environnement, Lavoisier, Paris 574

Liang W., Li J., Li J., Jin Y., 2009. Abatement of toluene from gas streams via ferro-electric 577

578 Maciuca A., Batiot-Dupeyrat C., Tatibouet J-M., 2012. Synergetic effect by coupling 579 photocatalysis with plasma for low VOCs concentration removal from airApplied Catalysis B: Environmental, 125, 432-438. 
Ma H., Chen P., Ruan R., 2001. $\mathrm{H}_{2} \mathrm{~S}$ and $\mathrm{NH}_{3}$ Removal by Silent Discharge Plasma and Ozone Combo-System, Plasma Chemistry and Plasma Processing 21, 611-624.

ManleyT.C., 1943. Transactions of the electrochemical society,. Proceedings of the 84th General Meeting, New York 84, p. 83.

Mfopara A., Kirkpatrick M. J., Odic E., 2009. Dilute methane treatment by atmospheric pressure dielectric barrier discharge: effects of water vapor, Plasma Chemistry and Plasma Processing 29, 91-102.

Mista W., Kacprzyk R., 2008. Decomposition of toluene using non-thermal plasma reactor at room temperature, Catalysis Today 137, 345-349.

Mobarak A. A., Farag H. A., Sedahmed G.H., 1997. Mass transfer in smooth and rough annular ducts under developing flow conditions Journal of applied electrochemistry. 27, 201207.

Mok Y. S., Lee Ho W., Hyun Y. J., Ham S. W., Nam I. S., 2001. Determination of Decomposition Rate Constants of Volatile Organic Compounds and Nitric Oxide in a Pulsed Corona Discharge Reactor, Korean J. Chem. Eng, 18, 711-718.

Mok Y.S., Kim D.H., 2011. Treatment of toluene by using adsorption and nonthermal plasma oxidation process Current applied physics, 11,S58-S62.

Ogata A., Ito D., Mizuno K., Kushiyama S., Gal A., Yamamoto T., 2002. Effect of coexisting components on aromatic decomposition in a packed-bed plasma reactor,Applied Catalysis A: General, 236, 9-15.

Ogata A., Ito D., Mizuno K., Kushiyama S., Gal A., Yamamoto T., 2004. Effect of coexisting components on aromatic decomposition in a packed-bed plasma reactor, Radiation Physics and Chemistry 69, 281-287. 
614 Ouni F., Khacef A., Cormier J. M., 2009. Gas Production from Propane Using Atmospheric

615 Non-thermal Plasma PlasmaChem Plasma Process, 29, 119-130.

616

617 Petit P., Vialle P.-J., Maciuca A., Batiot-Dupeyrat C., Tatibouet J.-M., Assadi A., Bouzaza A., 618 Wolbert D., Vallet C., 2013. Dispositif, système et procédé de traitement de gaz. CIAT, 619 ENSCR, CNRS. France. $\mathrm{N}^{\circ} 1350906$.

620

621 Rakness K., GordonG., LanglaisB., MasscheleinW., Matsumoto N., RichardY., Robson C. 622 M. , Somiy I. ,1996. Guideline for Measurement of Ozone Concentration in the Process Gas 623 From an Ozone Generator, 18, 209-229.

624

625

626

627

628

629

Schmidt-Szałowski K., Krawczyk K., Sentek J., Ulejczyk B., Górska A., Młotek M., 2011,

630

Hybrid plasma-catalytic systems for converting substances of high stability, greenhouse gases

631 and VOC. chemical engineering research and design 89, 2643-2651

632

633

634

Schmid S., Jecklin M.C., Zenobi R., 2010. Degradation of volatile organic compounds in a non-thermal plasma air purifier, Chemosphere, 79, 124-130.

635

636

Subrahmanyama Ch., Renken A., Kiwi-Minsker L., 2010. Catalytic non-thermal plasma

637 reactor for abatement of toluene, Chemical Engineering Journal 160, 677-682.

638

639

640

641

Subrahmanyam Ch., Magureanu M., Kiwi-Minsker L., Renken A., 2006. Catalytic abatement of volatile organic compounds assisted by non-thermal plasma: part II. Optimized catalytic electrode and operating conditions. ApplCatal B, 65, 157-162.

642

Thevenet F., Guaitella O., Puzenat E., Guillard C., Rousseau A., 2008. Influence of water 644 vapour on plasma/photocatalytic oxidation efficiency of acetylene, Applied Catalysis B:

645 Environmental, 84, 813-820.

646 
US EPA, 2008. Clean Air Act. US Code. Environmental Protection Agency. Washington, DC.

648

649 Vandenbroucke A. M., Morent R., De Geyter N., Leys Ch., 2011. Non-thermal plasmas for

650 non-catalytic and catalytic VOC abatement, Journal of Hazardous Materials 195, 30-54.

651

652

Vincent G., Marquaire P.M., Zahraa O., 2008. Abatement of volatile organic compounds 653 using an annular photocatalytic reactor: study of gaseous acetone, J.Photochem. Photobiol. A:

654 Chem. 197, 177-189.

655

656

Wang H., Li D., Wu Y., Li J., Guofeng L., 2009. Removal of four kinds of volatile organic 657 compounds mixture in air using silent discharge reactor driven by bipolar pulsed power, 658 Journal of Electrostatics 67, 547-555.

659

660

Yang H., An B., Wang Sh., Li L., Jin W., Li L., 2013. Destruction of 4-phenolsulfonic acid in 661 water by anodic contact glow discharge electrolysis, Journal of Environmental Sciences, 25(6)

662 1063-1070

663

664

YeZh., Zhao J., Huang H. y., Ma F., Zhang R., 2013. Decomposition of dimethylamine gas 665 with dielectric barrier discharge, Journal of Hazardous Materials 260, 32-39

666

667

Yoshida K., 2013, Diesel NOx aftertreatment by combined process using temperature swing 668 adsorption, nonthermal plasma, and NOx recirculation: NOx removal accelerated by 669 conversion of $\mathrm{NO}$ to $\mathrm{NO}_{2}$, Journal of the Taiwan Institute of Chemical Engineers, 44,1054-

670 1059 .

671

672

673

674

675

676

677

678

679

680 
Table captions

684

Table 1: Parameters of DBD plasma reactor

\section{Parameter}

Gastemperature

Gas pressure

Relative humidity
Value and domain Ambient (293 K)

Atmospheric pressure (1 atm)

20-90\%

Trimethylamineinlet concentration $55 \mathrm{ppm}$

Isovalericacidinlet concentration $55 \mathrm{ppm}$

Applied voltage

$12-29 \mathrm{kV}$

Gasflowrate

$2-6 \mathrm{~m}^{3} \mathrm{~h}^{-1}$

686

687

688

Table 2: Values of the kinetic coefficient with the model WMT

\begin{tabular}{|c|c|c|c|}
\hline Flow rate $\left(m^{3} h^{-1}\right)$ & 2 & 4 & 6 \\
\hline ollutar & TMA IVA & TMA IVA & TMA IVA \\
\hline$k_{d} \times 10^{2}\left(\mathrm{~m}^{2} \mathrm{~W}^{-1} \mathrm{~s}^{-1}\right)$ & 3.6 & 3.1 & 2.6 \\
\hline$R^{2}(\%)$ & 97.9198. & 98.9599. & 97.0099. \\
\hline
\end{tabular}

689

690

691

Table 3: Reynolds number and mass transfer coefficients

\begin{tabular}{|c|c|c|c|c|}
\hline \multicolumn{2}{|c|}{ Flow rate $\left(Q, \mathrm{~m}^{3} \mathrm{~h}^{-1}\right)$ Reynolds number } & \multicolumn{3}{|c|}{ Mass transfer coefficient $\left(k_{m} \times 10^{3}, \mathrm{~m} \mathrm{~s}^{-1}\right)$} \\
\hline & & IVA & & TMA \\
\hline 2 & 380 & 2.2 & 3.0 & \\
\hline 4 & 760 & 3.6 & 4.3 & \\
\hline 6 & 1140 & 4.4 & 5.4 & \\
\hline
\end{tabular}

692

693

694 Table 4: Values of parameters $\mathrm{k}_{\mathrm{d}}$ of model TM

Isovalericacid

$k_{d} \times 10^{2}\left(\mathrm{~m}^{2}(\mathrm{~W} \mathrm{~s})\right)^{-1}$ Correlation $(\%) k_{d} \times 10^{2}\left(\mathrm{~m}^{2}(\mathrm{~W} \mathrm{~s})\right)^{-1}$ Correlation (\%)

3.9
99

3.5
Trimethylamine

99 
Figure captions

699

Fig. 1: General electric schema of the DBD plasma reactor

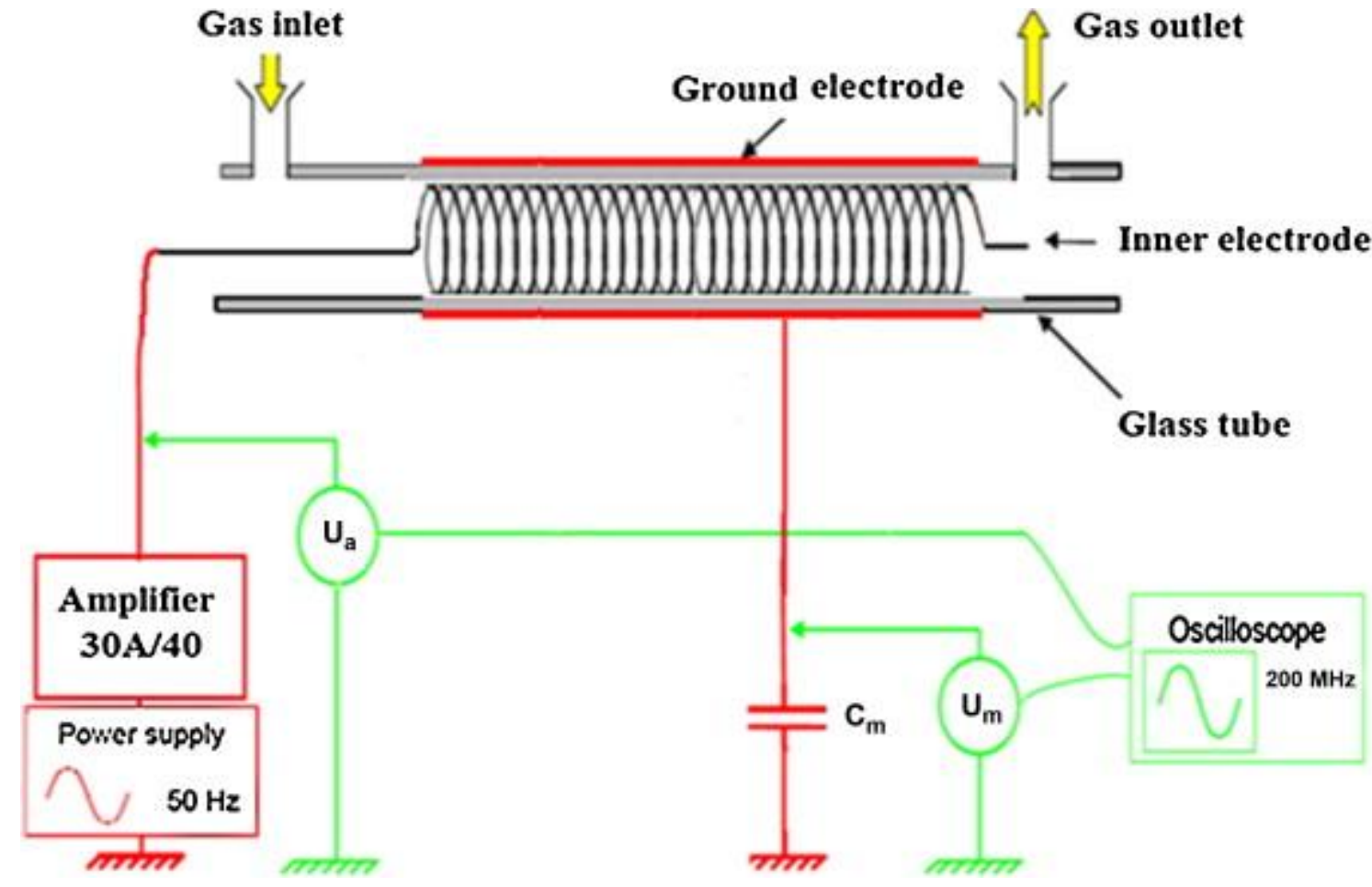

702

703

704

705

706

707

708

709

710

711

712

713

714

715

716 
719 Fig. 2.a: Experimental Set-Up

720 Fig. 2.b: Lissajous curve obtained at $50 \mathrm{~Hz}$. 
(a)

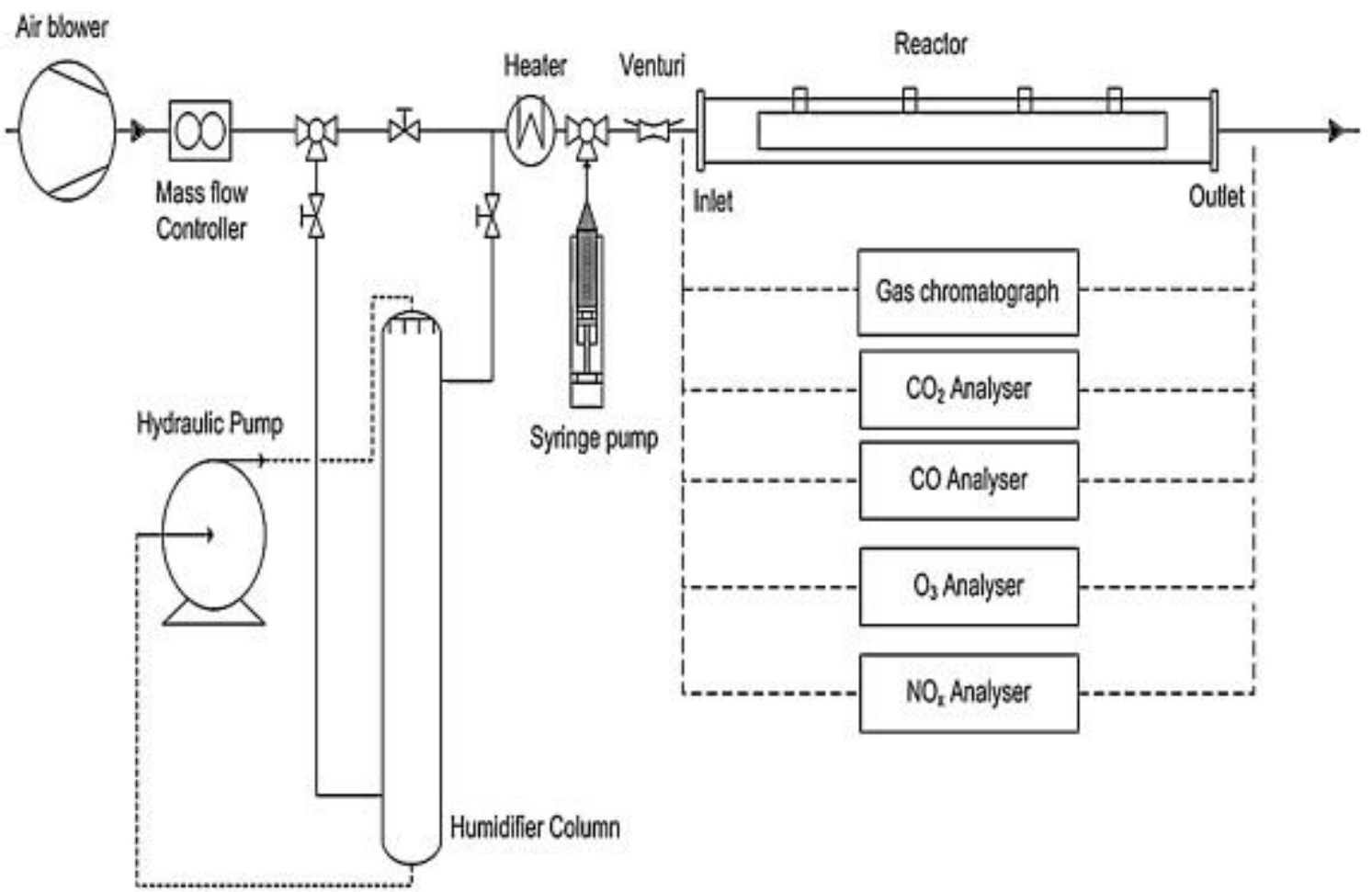

(b)

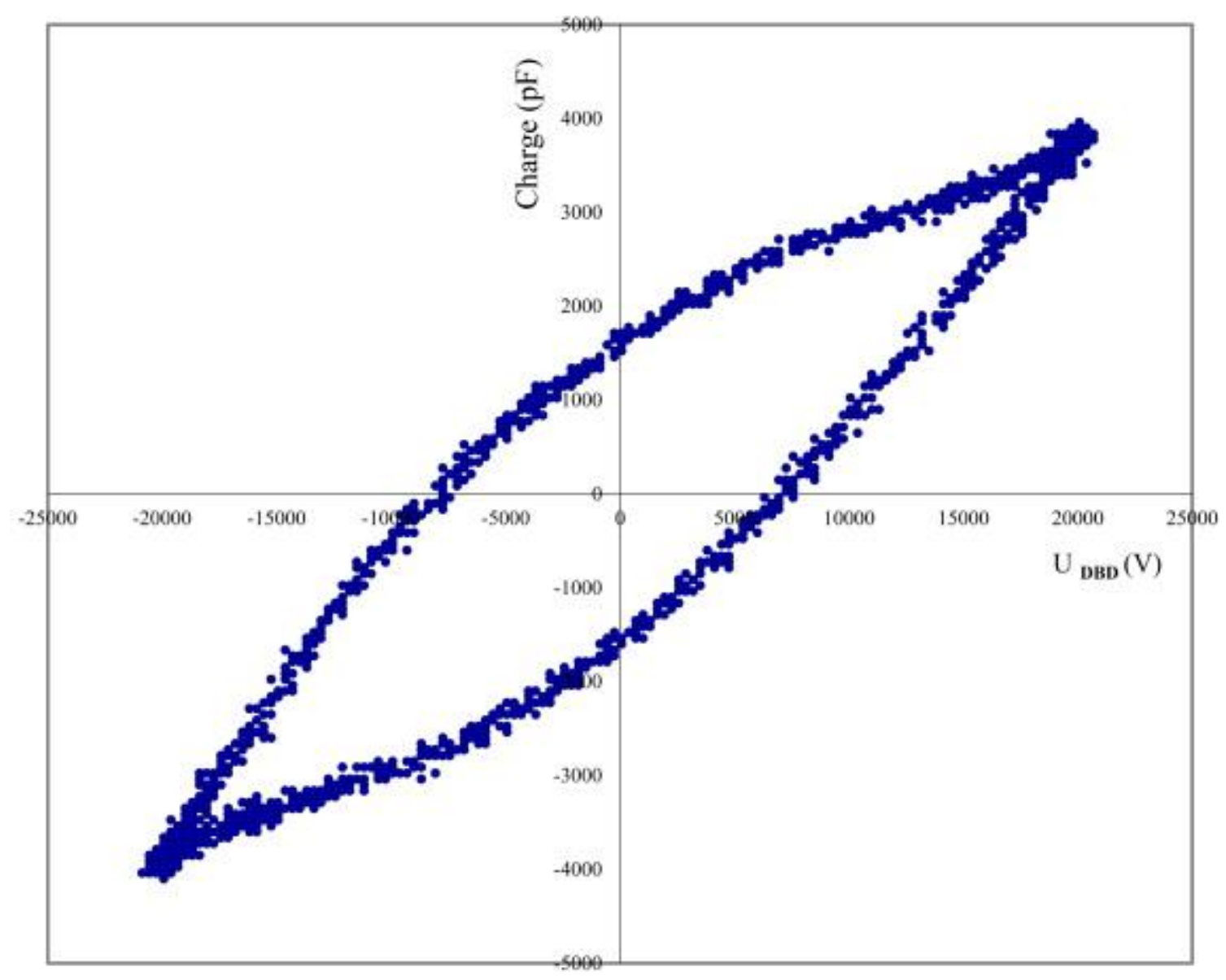

Fig. 3.a: Removal rate of IVA on the plasma reactor with the ED at different flowrate (Model:

$\left.723 \mathrm{MT},[\mathrm{IVA}]=55 \mathrm{ppm}, \mathrm{T}=20^{\circ} \mathrm{C}, \mathrm{RH}=50 \pm 5 \%\right)$. 
724 Fig. 3.b: Removal rate of TMA on the plasma reactor with ED at different flowrate (Model:

$\left.725 \mathrm{MT},[\mathrm{TMA}]=55 \mathrm{ppm}, \mathrm{T}=20^{\circ} \mathrm{C}, \mathrm{RH}=50 \pm 5 \%\right)$.
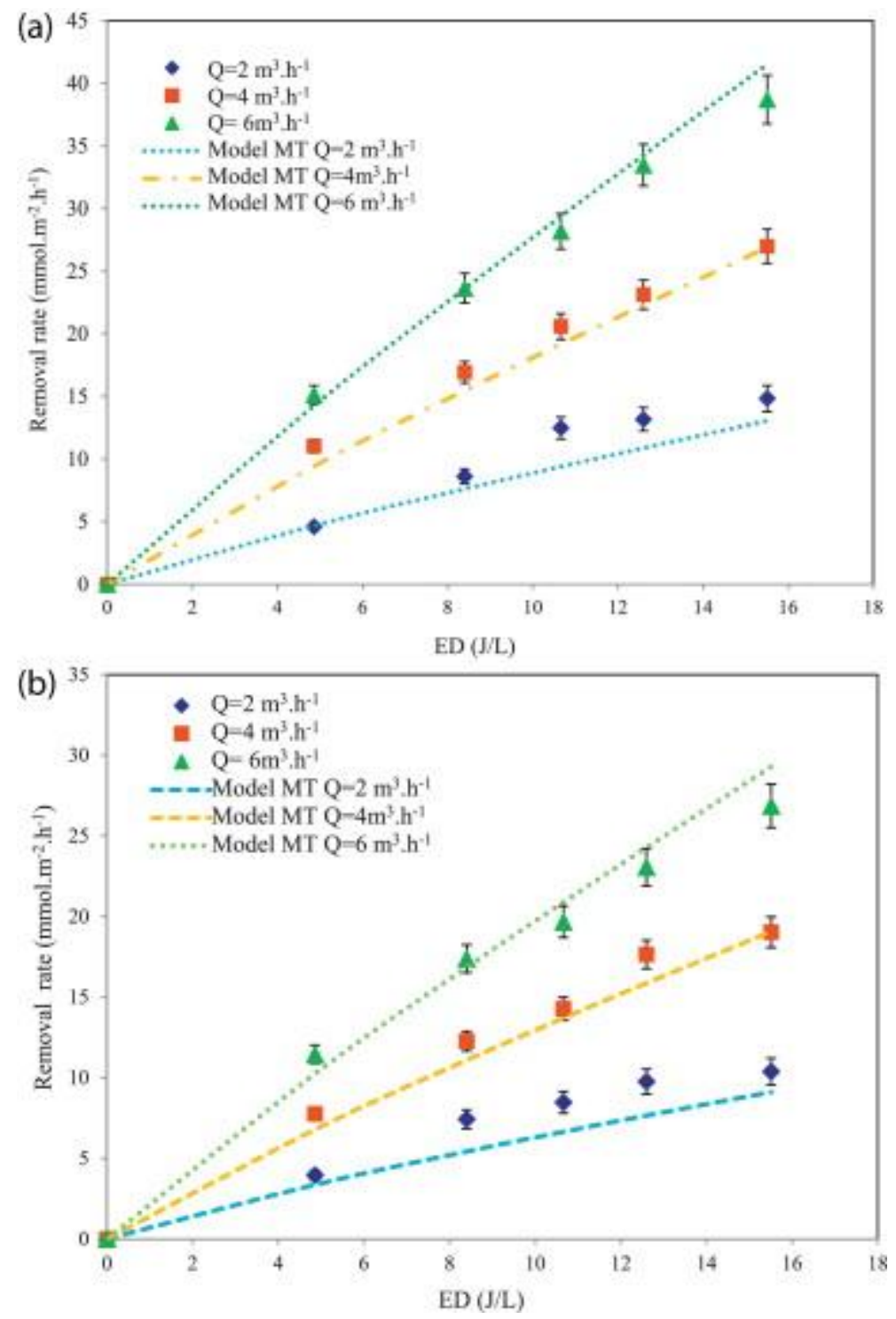

735 Fig. 4.a: Variation of the CO's and $\mathrm{CO}_{2}$ 's selectivities (\%) and balance of Carbon vs. ED 736 Isovaleric acid $\left(\mathrm{T}=20^{\circ} \mathrm{C}, \mathrm{RH}=25 \%, \mathrm{Q}=2 \mathrm{~m}^{3} \cdot \mathrm{h}^{-1}\right.$, [IVA $\left.]=55 \mathrm{ppm}\right)$. 
737 Fig. 4.b: Variation of the CO's and $\mathrm{CO}_{2}$ 's selectivities (\%) and balance of Carbon vs. ED 738 Trimethylamine $\left(\mathrm{T}=20^{\circ} \mathrm{C}, \mathrm{RH}=25 \%, \mathrm{Q}=2 \mathrm{~m}^{3} \cdot \mathrm{h}^{-1},[\mathrm{TMA}]=55 \mathrm{ppm}\right)$.
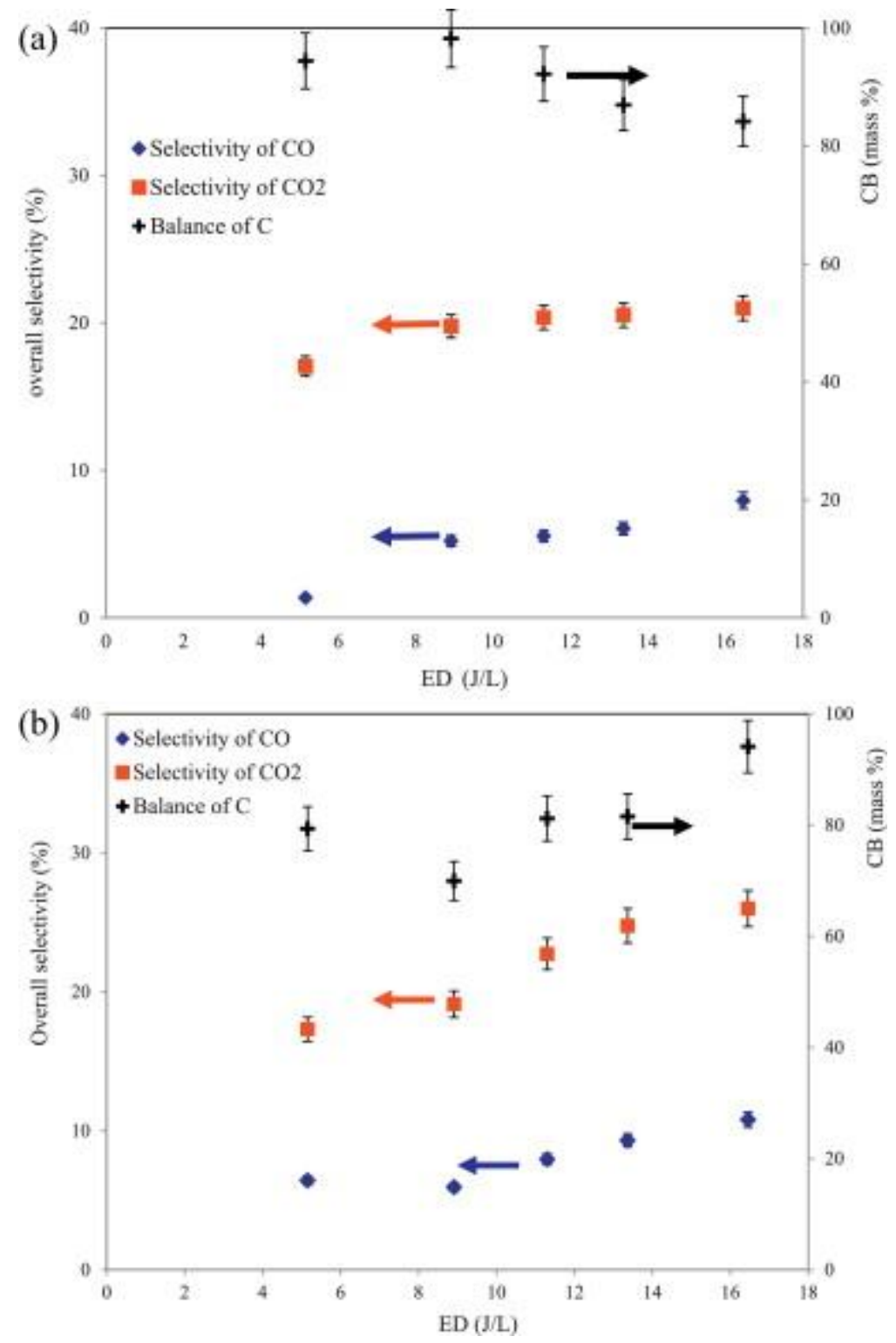

740

741

742

743

744

747 Fig.5.a.Variation of removal rate of IVA on the plasma reactor with relative humidity at 748 different $\mathrm{ED}\left([\mathrm{IVA}]=55 \mathrm{ppm}, \mathrm{T}=20^{\circ} \mathrm{C}, \mathrm{Q}=2 \mathrm{~m}^{3} \cdot \mathrm{h}^{-1}\right)$. 
Fig.5.b.Variation of removal rate of TMA on the plasma reactor with relative humidity at different density energy $\left([\mathrm{TMA}]=55 \mathrm{ppm}, \mathrm{T}=20^{\circ} \mathrm{C}, \mathrm{Q}=2 \mathrm{~m}^{3} \cdot \mathrm{h}^{-1}\right)$
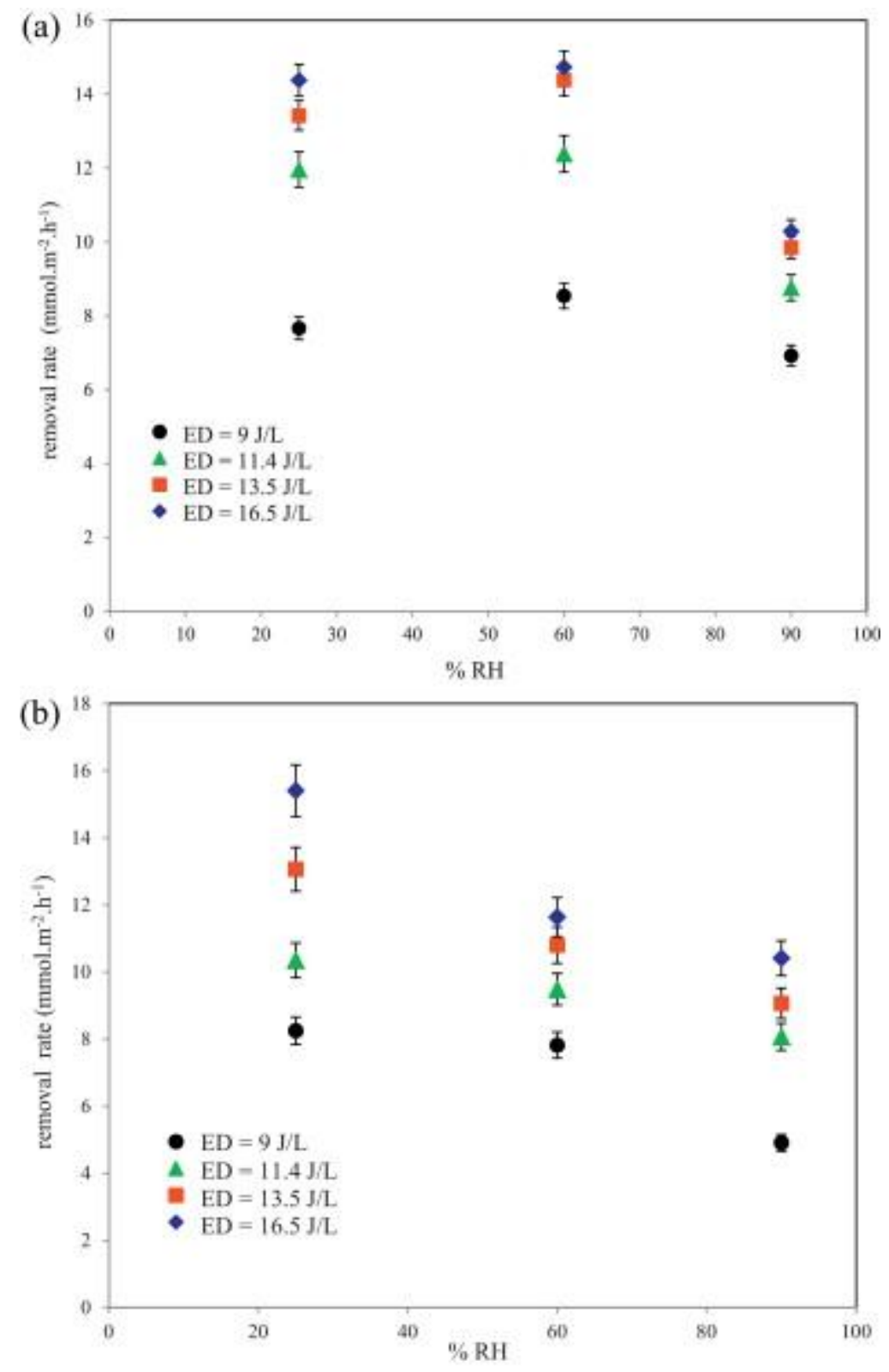

751

752

753

754

755

756

757

758 Fig. 6a Variation of $\mathrm{CO}_{2}$ selectivity vs \% $\mathrm{RH}$ at different values of $\mathrm{ED}([\mathrm{TMA}]=55 \mathrm{ppm}, \mathrm{T}=$ $\left.75920{ }^{\circ} \mathrm{C}, \mathrm{Q}=2 \mathrm{~m}^{3} \cdot \mathrm{h}^{-1}\right)$. 
Fig 6.b Variation of $\mathrm{CO}_{2}$ selectivity vs $\% \mathrm{RH}$ at different values of $\mathrm{ED}([\mathrm{IVA}]=55 \mathrm{ppm}, \mathrm{T}=$ $\left.76120{ }^{\circ} \mathrm{C}, \mathrm{Q}=2 \mathrm{~m}^{3} \cdot \mathrm{h}^{-1}\right)$.

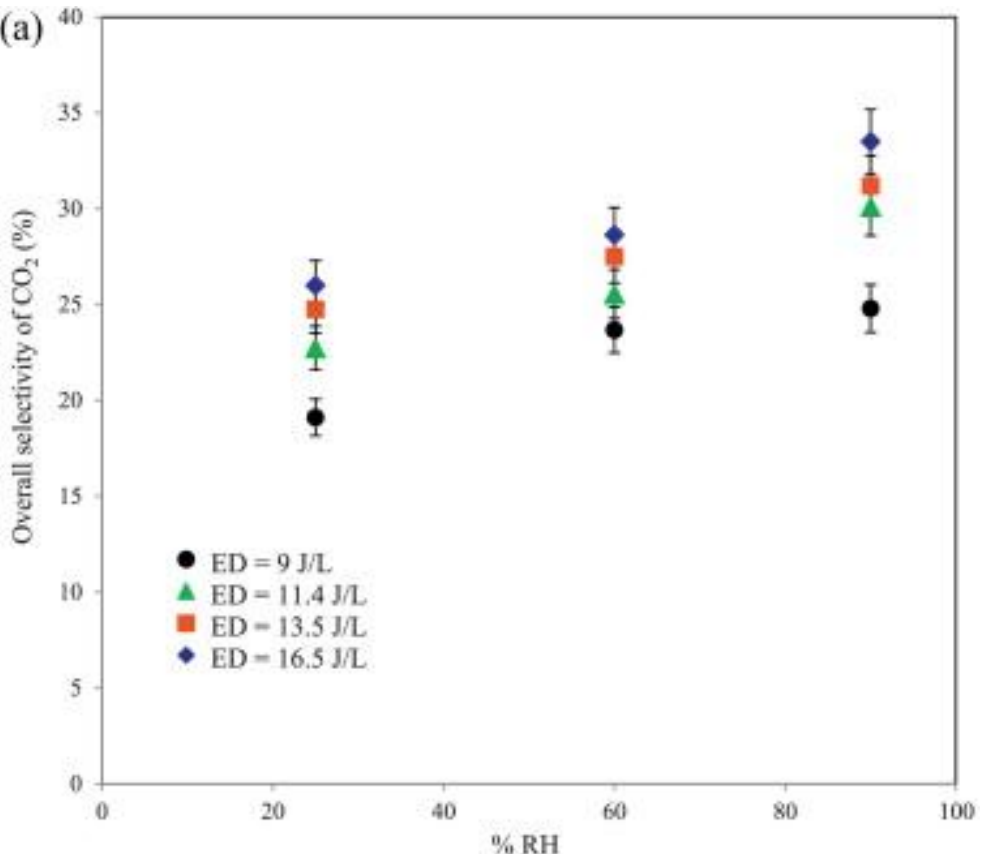

762

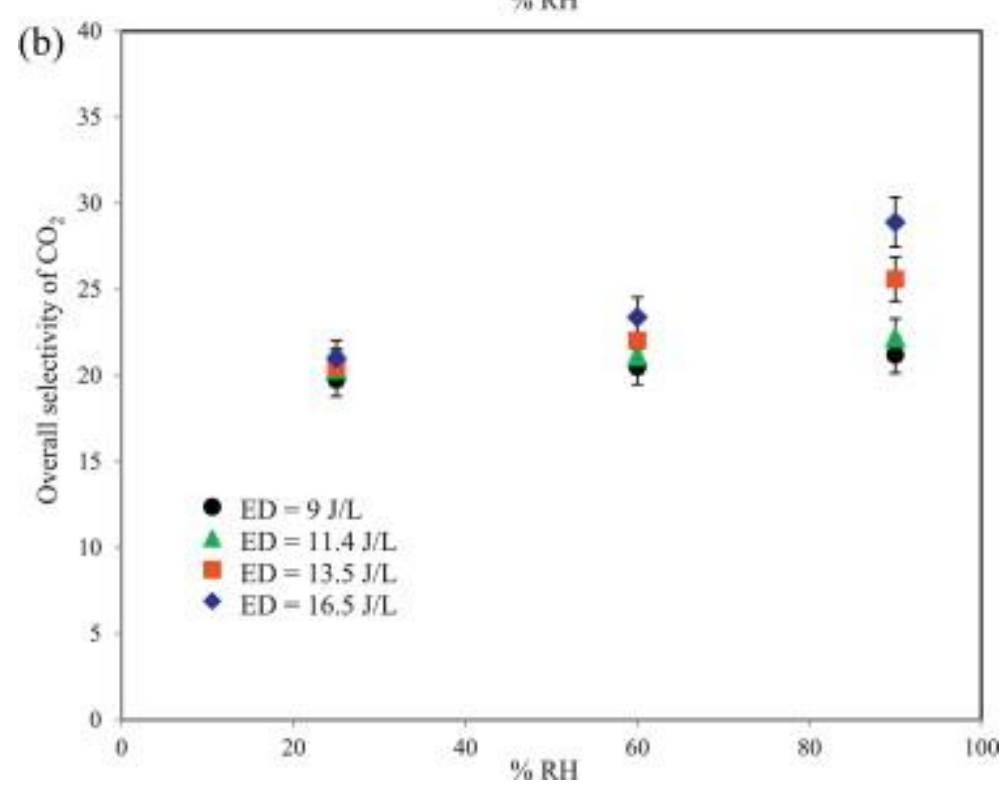

763

764

765

766

767

768 Fig 7.a Variation of ozone production vs \% RH at different values of ED ([TMA] $=55$ ppm, $\left.769 \mathrm{~T}=20^{\circ} \mathrm{C}, \mathrm{Q}=2 \mathrm{~m}^{3} \cdot \mathrm{h}^{-1}\right)$. 
Fig 7.b.:Variation of the ozone production vs $\% \mathrm{RH}$ at different values of ED ([IVA] $=55$

$\left.771 \mathrm{ppm}, \mathrm{T}=20^{\circ} \mathrm{C}, \mathrm{Q}=2 \mathrm{~m}^{3} \cdot \mathrm{h}^{-1}\right)$.
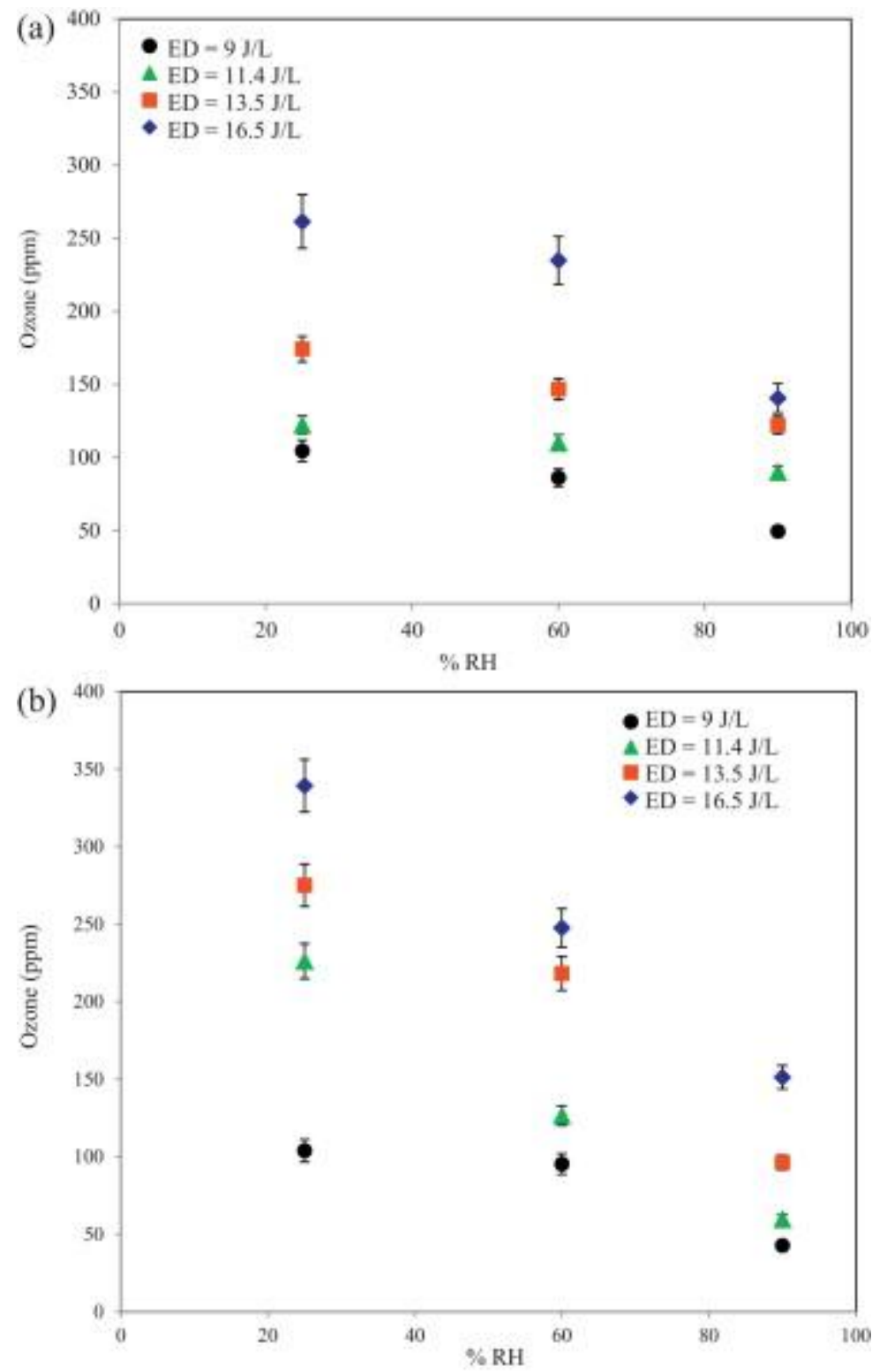

772

779 Figure 8.a: GC-MS spectrum of IVA byproducts $\left(\mathrm{ED}=13.4 \mathrm{~J} / \mathrm{L},[\mathrm{IVA}]=55 \mathrm{ppm}, \mathrm{T}=20{ }^{\circ} \mathrm{C}\right.$, $\left.780 \mathrm{Q}=2 \mathrm{~m}^{3} \cdot \mathrm{h}^{-1}\right)$.

Fig. 8.b: A possible pathway of isovaleric acid destruction on DBD plasma reactor. 
(a)

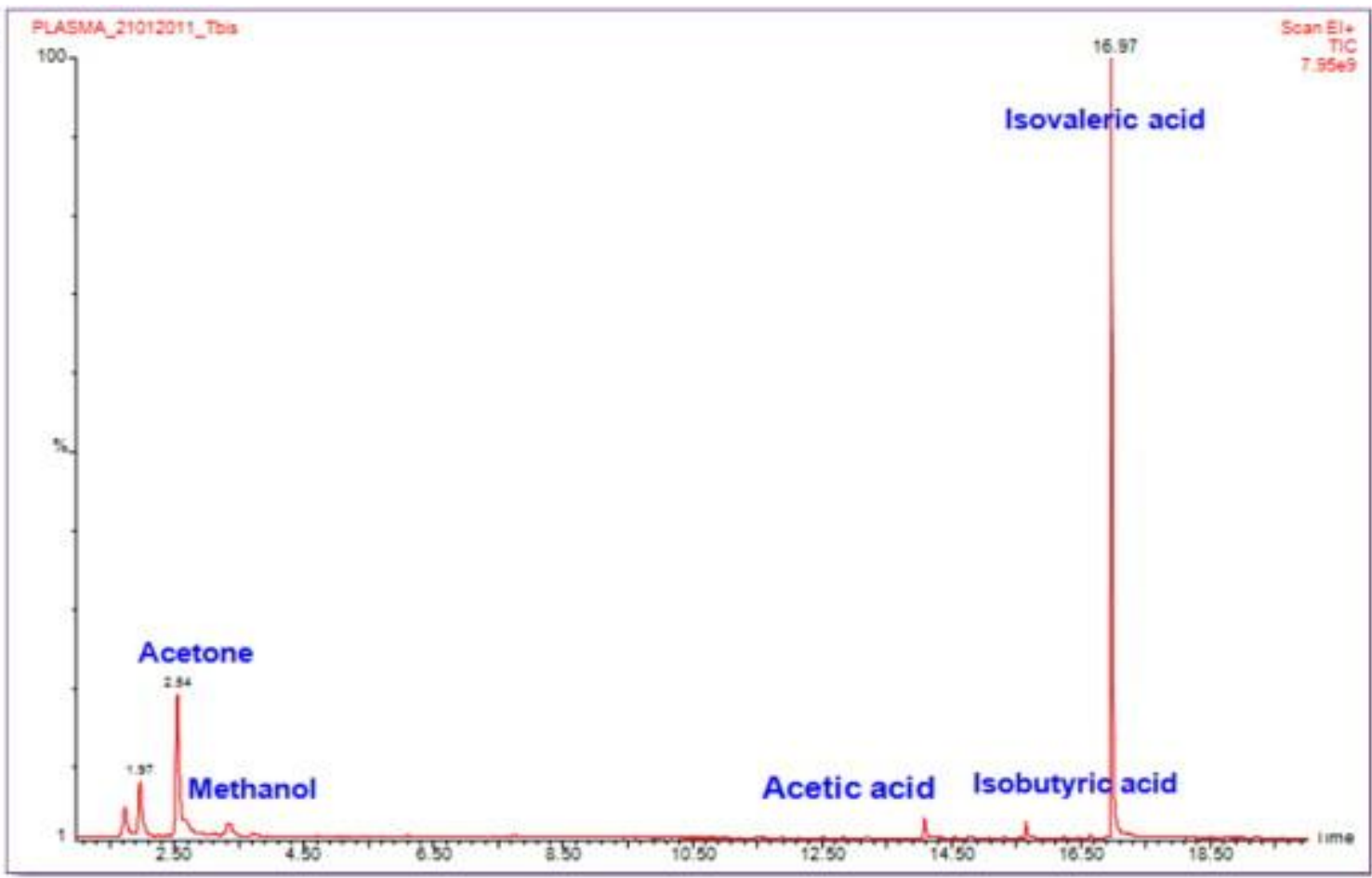

(b)

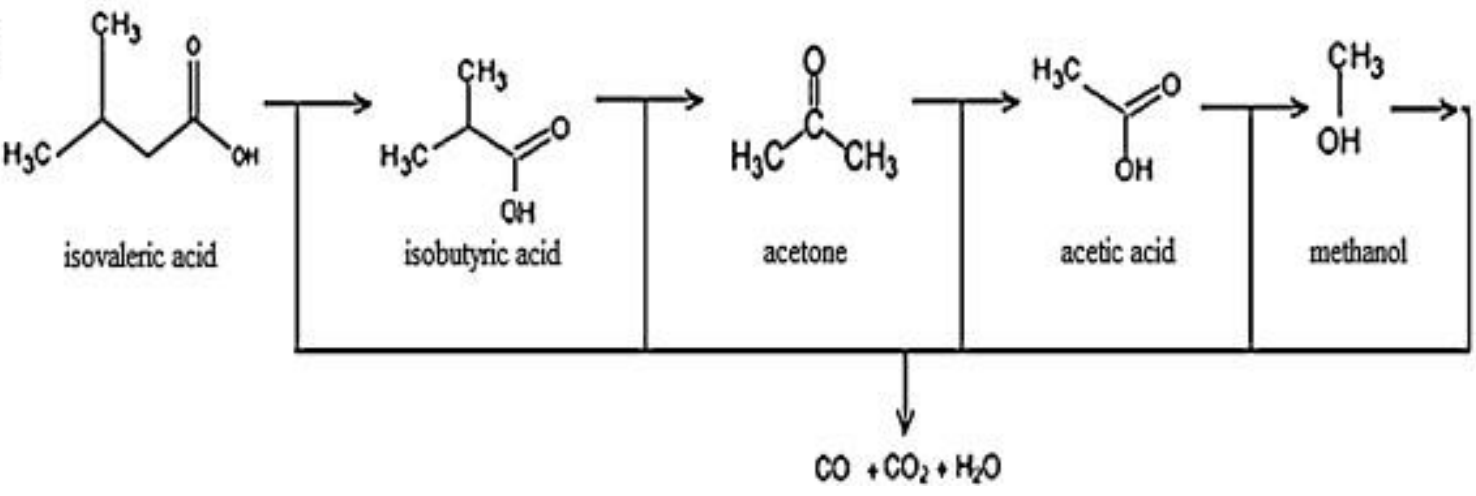

783

784

785

786

787 Fig.9.a: GC-MS spectrumof TMA by-products $\left(\mathrm{ED}=13.4 \mathrm{~J} / \mathrm{L},[\mathrm{TMA}]=55 \mathrm{ppm}, \mathrm{T}=20{ }^{\circ} \mathrm{C}, \mathrm{Q}\right.$ $\left.788=2 \mathrm{~m}^{3} \cdot \mathrm{h}^{-1}\right)$.

789 Fig. 9.b: Variation of amount of $\mathrm{NO}$ and $\mathrm{NO}_{\mathrm{x}} \mathrm{vs} \mathrm{ED}(\% \mathrm{RH}=50 \%$, [TMA] $=55 \mathrm{ppm}, \mathrm{T}=20$

$\left.790{ }^{\circ} \mathrm{C}, \mathrm{Q}=2 \mathrm{~m}^{3} \cdot \mathrm{h}^{-1}\right)$. 
(a)
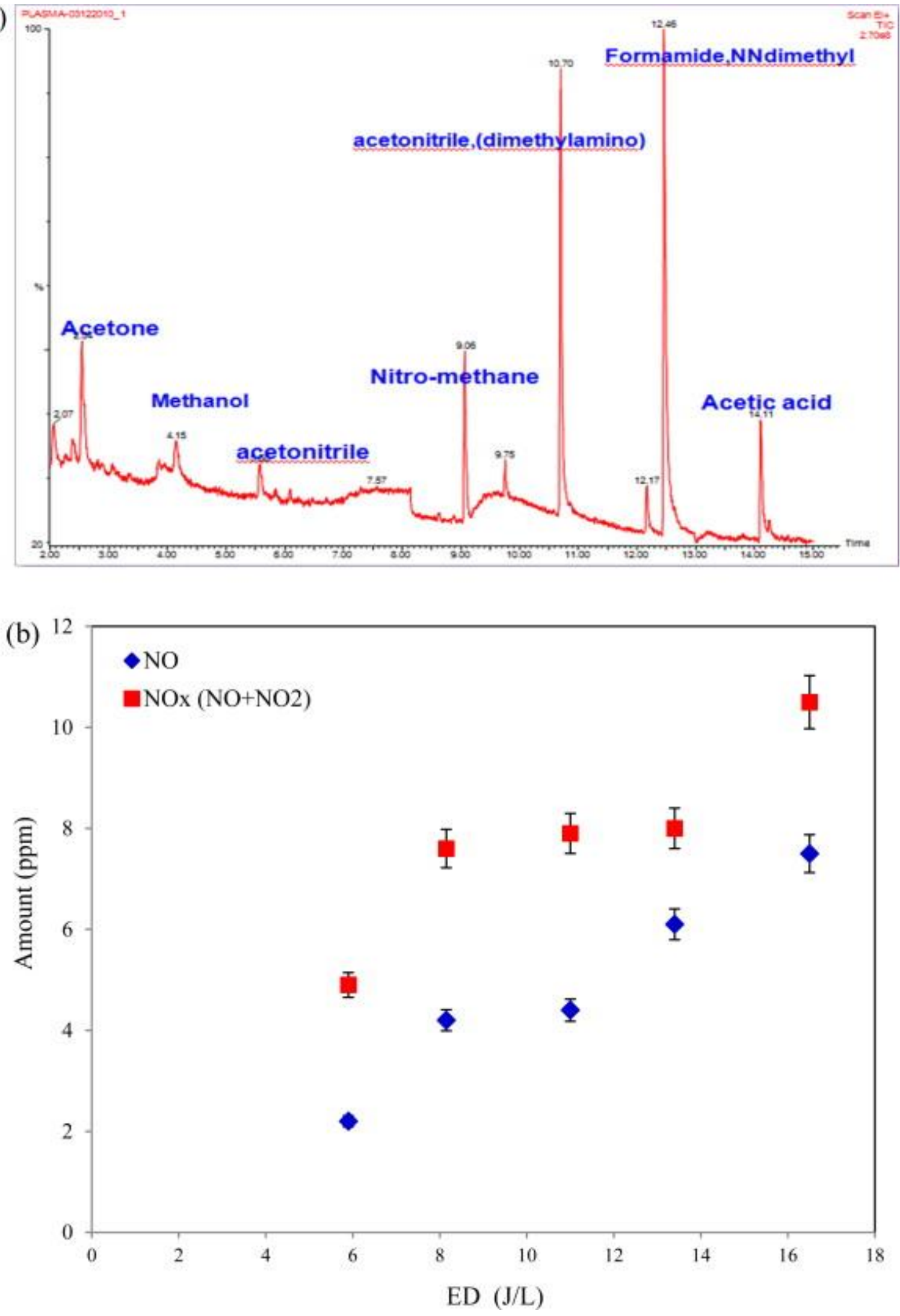